\title{
MODEL AKAD QARDHUL HASAN PADA USAHA MIKRO KECIL MENENGAH
}

\author{
Rini Rahayu Kurniati ${ }^{1}$ ), Afifuddin ${ }^{2)}$, Sri Nuring Wahyu ${ }^{3)}$ \\ Fakultas Ilmu Administrasi Universitas Islam Malang, \\ Jl.MT Haryono 193 Malang - Jawa Timur \\ E.mail: rinirahayu.kurniati@gmail.com
}

\author{
Akuntansi Bisnis dan \\ Manajemen (ABM), \\ Volume 27 \\ Nomor 1 \\ Halaman 29-40 \\ Bulan April, Tahun 2020 \\ ISSN 0854-4190 \\ E-ISSN 2685-3965
}

\begin{abstract}
The purpose of the research was to analyze the qardhul hasan contract model in small and medium entrepreneurs (MSMEs) in the context of economic development in Batu City and to analyze the role of the qardhul hasan contract in small and medium entrepreneurs (MSMEs) in the context economic development in Batu City. This research uses qualitative descriptive method by collecting data using analytical technical triangulation through head micro unit of Sharia BRI Batu City and qarhul hasan customers as informans. The results showed that the qardhul hasan contract model was in the form of: a contract based on sharia concept, namely the provision of loan funds for businesses based on customers who needed and paid back according to ability. The role of the qardhul hasan contract is to create a sense of independence, create creativity to start and develop a business.
\end{abstract}

Keywords: Model; Qardhul Hasan Contract; SMEs

Informasi Artikel

Tanggal Masuk:

8 April 2020

Tanggal Revisi:

15 April 2020

Tanggal Diterima:

20 April 2020

\begin{abstract}
Abstrak
Tujuan penelitian untuk menganalis model akad qardhul hasan pada pengusaha kecil dan menengah (UMKM) dalam perkembangan perekonomian di BRI Syariah Kota Batu dan untuk menganalisis peran akad qardhul hasan pada pengusaha kecil dan menengah (UMKM) dalam perkembangan perekonomian di BRI Syariah Kota Batu. Penelitian ini menggunakan metode kualitatif deskriptif dengan pengumpulan data menggunakan teknis analitis triangulasi melalui unit head micro BRI Syariah Kota batu dan nasabah qarhul hasan sebagai informan. Hasil penelitian diperoleh bahwa model akad qardhul hasan berupa: akad yang berdasarkan konsep syariah yaitu pemberian dana pinjaman untuk usaha berdasarkan pada nasabah yang membutuhkan dan membayar pengembalian sesuai kemampuan. Peran akad qardhul hasan yaitu dapat menciptakan rasa kemandirian, menciptakan kreativitas untuk memulai dan mengembangkan usaha.
\end{abstract}

Kata Kunci: Model; Akad Qardhul Hasan; UMKM 


\section{PENDAHULUAN}

Kota Wisata Batu masih akan mengandalkan tiga sektor dalam menggenjot Produk Domestik Regional Bruto (PDRB). Ketiga sektor andalan itu, yakni usaha jasa perdagangan, sektor usaha perhotelan, dan sektor usaha restauran. Tiga sektor andalan tersebut mampu berkontribusi hingga 48 persen terhadap perekonomian Kota Batu. Kontribusi sektor usaha pertanian ternyata hanya berkontribusi 19 persen dan sekitar 14 persen dari sektor usaha keuangan, komunikasi dan sisa persentase dari sektor usaha lain-lain (Muiz, 2015). Adapun jumlah penduduk berdasarkan mata pencaharian yaitu: (1) Pertanian: 34.546, (2) Penggalian: 477, (3) Industri: 5.002, (4) Listrik dan Air Bersih: 58, (5) Kontruksi: 5.744, (6) Perdagangan: 18.869, (7) Transportasi dan Komunikasi: 5.981, (8) Keuangan: 1.287, (9) Jasa dan Lain-lain: 75.104. Jumlah keseluruhan 147.067 (BAPPEDA, 2019).

Persentase jumlah penduduk miskin di Kota Batu naik 0,12 poin dibanding tahun 2014. Ada total 9.430 atau 4,71 persen penduduk miskin dari total 218.806 jiwa penduduk di Kota Batu. Indikator kemiskinan ditentukan oleh jumlah pengeluaran perkapitanya. Di batu, garis kemiskinannya adalah Rp 380.395 (penjumlahan garis kemiskinan makanan dan non makanan). Secara keseluruhan pertumbuhan ekonomi daerah regional maupun nasional memang mengalami penurunan akibat ekonomi global yang mengalami kontraksi dan cenderung tidak stabil, namun, pertumbuhan ekonomi Kota Batu masih positif. Di Jatim persentasi kemiskinan 12,34 persen dan Nasional 11,18 persen (Arowana, 2017). Masyarakat Kota Batu sebagian besar bermata pencaharian sebagai petani dan pedagang dan tidak semua dalam taraf ekononomi menengah keatas namun masih banyak yang taraf ekonominya masih menengah kebawah. Mereka membutuhkan bantuan dana kebajikan. Dana kebajikan dalam lembaga keuangan syariah berupa qardhul hasan. Qardhul hasan nantinya banyak menunjang keberlangsungan usaha mereka. Salah satu manfaat program qardhul hasan secara langsung yang bisa dirasakan masyarakat yang sedang kesulitan dana adalah mendapatkan talangan jangka pendek.

Qardhul hasan memiliki tujuan untuk membantu rakyat kecil dengan dana yang diperoleh dari infak, shadaqah dan sumbangan. Qardhul hasan (Dana kebajikan) perlu disalurkan secara merata untuk peningkatan perekonomian masyarakat kecil dalam mengembangkan usahanya sehingga diharapkan akan terwujud peningkatan kesejahteraan masyarakat kecil tersebut. Selain kesejahteraan masyarakat kecil terwujud maka terwujud pula Islam yang penuh dengan damai rahmatan lil'alamin yaitu Islam yang penuh dengan kelembutan, kasih sayang serta keharmonisan dan bukan yang menebarkan kekerasan. Qardhul hasan merupakan salah satu cara penguatan ekonomi untuk memperbaiki laju perekonomian pengusaha kecil dan menengah.

PT. Bank Rakyat Indonesia Syariah (BRI Syariah) mewujudkan program qardhul hasan yang berlandaskan penyaluran pembiayaan yang didasarkan pada dasar hukum yang termuat dalam surat edaran BRI Syariah NO.SE.B.001-PDR/03-2016 tanggal 31 Maret 2016 tentang Ketentuan Penggunaan Dana Kebajikan BRI Syariah, yang salah satu bentuknya adalah penyaluran dana kebajikan berupa qardhul hasan terhadap faedah sosial yang disini berbentuk pemberdayaan masyarakat. Pengimplementasian program qardhul hasan ini juga tidak boleh tebang pilih dalam melaksanakannya baik 
dari hulu yakni kantor pusat sampai ke hilir yaitu kantor cabang bahkan sampai kantor cabang pembantu sekalipun. Sebagai contohnya adalah BRI Syariah Kota Batu.

Penelitian (Wulandari, 2019) tentang Enhancing the role of Baitul Maal in giving Qardhul Hassan financing to the poor at the bottom of the economic pyramid. Menemukan bahwa BMT di Indonesia membutuhkan beberapa struktur dan peran spesifik untuk menjadi efektif. Secara khusus, ada kebutuhan untuk memisahkan fungsi Baitul Maal dari Baitul Tamwil untuk meningkatkan perannya ketika memberikan pembiayaan qardhul hasan pada orang-orang Bottom of The Economic Pyramid (BOP). Penelitiannya juga menemukan bahwa peran Baitul Maal mengurangi angka kemiskinan. Penelitian (Zauro, Zauro, Saad, \& Sawandi, 2020) tentang Enhancing socio-economic justice and financial inclusion in Nigeria: The role of zakat, Sadaqah and Qardhul Hassan, menjelaskan bahwa qardhul hasan sebagai instrumen yang mendorong redistribusi kekayaan yang efisien dan efektif antara yang kaya dan yang miskin dan sebagai sarana untuk meningkatkan keadilan sosial-ekonomi dalam komunitas muslim Nigeria.

Menurut Hannanong (2018) menjelaskan dalam penelitiannya tentang Al-Qardh Al-Hasan: Soft and Benevolent Loan Pada Bank Islam bahwa manfaat akad al qardh adalah membantu nasabah yag membutuhkan dana cepat, sekaligus salah satu ciri pemberi dana antara bank syariah dan bank konvensional yang didalamnya terkandung misi sosial, disamping misi komersial, juga meningkatkan citra baik dan meningkatkan loyalitas masyarakat pada bank syariah. Mencermati penelitian-penelitian yang sudah disajikan maka dapat diambil celah bahwa model akad qardhul hasan tidak menjadi pembahasan, oleh karena itu dalam penelitian ini memunculkan model akad qardhul hasan untuk dijadikan perbedaan dari penelitian sebelumnya.

Berdasarkan uraian tersebut maka perlu dilakukan penelitian tentang "Model Dan Peran Akad Qardhul Hasan Pada Pengusaha Kecil Dan Menengah (UMKM) Dalam Perkembangan Perekonomian Di BRI Syariah Cabang Kota Batu" Penelitian ini diharapkan akan dapat memberikan gambaran serta diskripsi tentang model dan peran Akad Qardhul Hasan yang tentunya harapannya akan dapat membantu pelaku UMKM itu sendiri baik dari segi pendapatan dan ekonomi. Penelitian ini tentunya juga turut membantu program pemerintah untuk meningkatkan produktivitas, pendapatan serta perkembangan ekonomi di Indonesia secara umum dan di Kota Batu secara khusus.

\section{KAJIAN PUSTAKA}

\section{Akad Qardhul Hasan}

Qordhul Hasan atau Al- Qard merupakan fasilitas pembiayaan yang diberikan oleh bank sayariah dalam membantu pengusaha kecil. Pembiayaan qardhul hasan ini diberikan tanpa ada imbalan dengan tujuan untuk pengembangan usaha kecil (Ismail, 2013). Berdasar dari pengertian ini dapat diartikan bahwa dengan pembiayaan qardhul hasan maka usaha kecil akan berkembang dan sekaligus mewujudkan pembangunan ekonomi. Qordhul Hasan dalam pemberian harta kepada orang lain yang dapat diatagih atau diminta kembali atau dengan kata lain meminjamkan tanpa mengharapakan imbalan. (Antonio, 2001). (Menurut Madzhab Hambali, Qardhul hasan adalah menyerahkan harta kepada seseorang yang dapat mengambil manfaat dan ia mengembalikan gantinya, sedangkan menurut Madzhab Syafi'i, Qardhul hasan adalah akad perjanjian yang dibuat oleh pemiutang untuk memindahkan pemilikan harta 
kepada peminjam, di mana peminjam berjanji akan mengembalikan semula barang gantinya. Kalimah al qardh sebenarnya sudah cukup menggambarkan suatu muamalah yang baik yang tidak memerlukan ganjaran faedah atau keuntungan, bahkan setiap faedah atau keuntungan ke atas pinjaman adalah riba yang dilarang oleh Allah. Kalimah Al hasan yang baik itu bermaksud pinjaman yang diberikan itu adalah sematamata suatu muamalah yang baik bertujuan untuk berbuat kebajikan kerana Allah dengan membantu seseorang. Bukan untuk tujuan berniaga atau mencari keuntungan atau mengharapkan faidah apa-apa. Qardh merupakan pinjaman kebajikan/lunak tanpa imbalan.

Adapun obyek dari pinjaman qardh biasanya adalah uang yang merupakan transaksi pinjaman murni tanpa bunga ketika peminjam mendapatkan uang tunai dari pemilik dana (dalam hal ini bank) dan hanya wajib mengembalikan pokok utang pada waktu tertentu di masa akan datang (Ascarya, 2012). Secara umum, arti Qardhul hasan serupa dengan arti jual beli, karena qardh adalah pengalihan hak milik harta atas harta. Qardhul hasan juga termasuk jenis salaf. Dalam literatul fiqh salaf as sholih Qardhul hasan dikatagorikan dalam akad tathowui' atau akad saling bantu membantu dan bukan transaksi komersial (Antonio, 2001). Menurut Muslehuddin (2004), Qardhul hasan adalah suatu jenis pinjaman pendahuluan untuk kepentingan peminjaman. Ini meliputi semua bentuk barang yang bernilai dan bayarannya juga sama apa yang dipinjamkan. Pinjaman tidak mendapatkan nilai yang berlebih karena itu akan merupakan riba' yang dilarang dengan keras. Qardhul hasan sebagai salah satu landasan transaksi produk pembiayaan perbankan syariah mengacu kepada UU no. 21 tahun 2008 pasal 1 ayat (25) huruf d, pasal 19 ayat (1) dan (2) huruf e, dan pasal 21 huruf $b$ angka 3. Menurut UU ini al qardh di artikan sebagai "akad pinjaman dana kepada nasabah dengan ketentuan bahwa nasabah wajib mengembalikan dana yang diterimanya pada waktu yang telah disepakati. Menurut Fatwa DSN Indonesia : (1) Bahwa Lembaga Keuangan Syariah (LKS) di samping sebagai lembaga komersial, harus dapat berperan sebagai lembaga sosial yang dapat meningkatkan perekonomian secara maksimal. (2) Bahwa salah satu sarana peningkatan perekonomian yang dapat dilakukan oleh LKS dalah penyaluran dana melalui prinsip Qardhul hasan, yakni suatu akad pinjaman kepada nasabah dengan ketentuan bahwa nasabah wajib mengembalikan dana yang diterimanya kepada LKS pada waktu yang telah disepakati oleh LKS dan nasabah (MUI, 2001) .

Secara umum, Qardh hasan diartikan sebagai infak di jalan Allah, didalam jihad dan peperangan demi menegakkan kebenaran dan bersedekah kepada para fakir miskin dan orang-orang yang membutuhkan. Ada juga yang mengatakan: Qardh hasan itu adalah bentuk transaksi pinjaman yang benar-benar bersih dari tambahan/bunga. Infak dan sedekah pada para fakir miskin merupakan suatu amalan yang nantinya akan diperhitungkan dihari esok (akhirat) nanti. Akad Qardhul hasan terdiri atas : (a) Pelaku akad, yaitu muqtaridh (peminjam) disebut pihak yang membutuhkan dana, dan muqridh (pemberi pinjaman) disebut pihak yang memiliki dana; (b) Obyek akad yaitu gardh (dana); (c) Tujuan, yaitu 'iwad atau couteralue jumlah pinjaman tanpa imbalan, dan (d) Shigah yaitu ijab dan qabul. Syarat dari akad qardh atau qardhul hasan yang harus dipenuhi dalam transaksi adalah: Kerelaan kedua belah pihak dan Dana digunakan untuk sesuatu yang bermanfaat dan halal (Ascarya, 2012). 
Hasil penelitian yang dilakukan oleh Putri \& Suryadi (2018) menerangkan bahwa tidak terlihat jelas antara pemisah sumber atau aliran dana sehingga tidak tersajikan dengan nyata apakah dana yang dimaksud adalah hasil dari usaha atau pengumpulan dana zakat. (a) Sasaran pembiayaan qordhul hasan hanya ditujukan kepada karyawan yang ada di lingkup YKPI saja. Hal ini jauh dari fatwa bahwa qardhul hasan diberikan kepada nasabah yang memerlukan. (b) Perlakuan akuntansi pembiayaan qardhul hasan pada BMT Al Ittihad belum berjalan dengan baik. Hal ini dapat dilihat dari pencatatan dan penjurnalan pada saat transaksi akad disepakati, pembayaran angsuran disertai dengan infaq/sedekah yang diberikan oleh nasabah kepada BMT tidak melakukan pencatatan atau penjurnalan.

Di lain pihak Bilal (2017) mengungkapkan dalam penelitiannya bahwa: (a) Kebijakan Baitul Maal dalam penyaluran qordhul hasan adalah dengan cara membentuk kelompok usaha karena dinggap mudah dalam hal pengwasan dan pembinaan sehingga kemungkinannya sangat kecil apabila terjadi kemacetan. (b) Sistem distribusi dalam penyaluran pembiayaan ini adalah dengan sistem bertahap, maksudnya anggota tidak semena-mena langsung diberi dana tetapi harus aktif terlebih dahulu di setiap pertemuan dan sosialisai pembinaan. Sedangkan sasaran distribusi anggota pembiayaan adalah masyarakat menengah kebawah yang mempunyai usaha kecil.

\section{Pengusaha Kecil dan Menengah (UMKM)}

Hasil penelitian Karimah (2015) Menunjukkan persepsi responden terhadap tingkat pendapatannya setelah mendapatkan pembiayaan Qardhul hasan. Sebesar 92\% atau sebanyak 46 responden mengalami peningkatan pendapatan setelah mendapatkan pembiayaan Qardhul Hasan karena adanya peningkatan omzet usaha yang didapatkan. Sebesar $8 \%$ responden atau sebanyak 4 orang responden menyatakan bahwa tingkat pendapatan mereka tidak mengalami peningkatan setelah mendapatkan pembiayaan Qardhul Hasan karena peningkatan omzet usaha yang didapatkan lebih kecil dari peningkatan pengeluaran rumah tangga responden.

Hafni (2015) dalam penelitiannya mengatakan bahwa Usaha Mikro, Kecil, dan Menengah (UMKM) merupakan stimulan perekonomian pada negara berkembang. Tidak heran apabila pernah terjadi krisis yang melanda dunia bahkan Amerika Serikat, tetapi krisis tersebut hampir tidak dirasakan oleh negara Indonesia yang kegiatan perekonomiannya dijalankan oleh UMKM. Selain potensi yang dimiliki terdapat keunggulan-keunggulan UMKM dibandingkan dengan usaha besar, yaitu: (1) Inovasi dalam teknologi yang telah dengan mudah terjadi dalam pengembangan produk. (2) Berbasis pada sumber daya lokal sehingga dapat memanfaatkan potensi secara maksimal dan memperkuat kemandirian. (3) Kemampuan menciptakan lapangan kerja cukup banyak atau penyerapan tenaga kerja. (4) Fleksibilitas dan kemampuan menyesuaikan diri terhadap kondisi pasar dengan cepat dibandingkan dengan perusahaan dalam skala besar yang pada umumnya birokratis. (5) Terdapat dinamisme manejerial dan peranan kewirausahaan. (6) Dimiliki dan dilaksanakan oleh masyarakat lokal sehingga mampu mengembangkan sumber daya manusia. (7) Tersebar dalam jumlah yang banyak sehingga merupakan alat pemerataan pembangunan yang efektif.

Hasil penelitian Falikhatun \& U.A (2016) menjelaskan bahwa: (1) Qardhul hasan dimaknai sebagai sedekah. Hal tersebut tertuang dalam implementasi pembiayaan 
qardhul hasan yang dilakukan dengan dua cara yaitu pinjaman dana produk dan pemberian dana sosial. (2) Sumber dana qardhul hasan berasal dari tiga sumber yaitu dana non halal, denda, dan infaq shadaqah. (3) Model implementasi qardhul hasan tersebut sudah sesuai amanah dan teori maslahah. Di sisi lain Sunariani (2017) menunjukkan bahwa faktor penghambat UMKM, yaitu modal, sumber daya manusia, akses perbankan, dari sifat produk seumur hidup pendek, dan terbatasnya akses pasar baik di pasar nasional maupun internasional.

Program di bawah yurisdiksi UMKM di Provinsi Bali dapat dilakukan di berkolaborasi dengan pemerintah, perbankan, perusahaan, koperasi, lembaga pemerintahan desa, perguruan tinggi berkolaborasi melalui bisnis inkubator. Berdasarkan penelitian yang dilakukan, dapat dirumuskan rekomendasi kebijakan, di bawah yurisdiksi mitra program antara pemerintah dan UMKM di Provinsi Bali. Pemerintah perlu menyederhanakan prosedur perizinan, murah dan cepat melalui satu atap.

\section{METODE PENELITIAN}

Metode pengambilan sample yang digunakan dalam penelitian ini ditentukan secara purposive, yaitu menentukan informan yang dianggap tepat dengan sengaja, yang mempunyai pertimbangan-pertimbangan tertentu. Alasan digunakannya teknik purposive sampling karena peneliti hanya diberikan kesempatan oleh BRI Syariah Kota Batu meneliti di daerah Ngaglik. Menurut pihak bank daerah ini yang banyak menggunakan pinjaman dana qardhul hasan, sehingga peneliti mengkhususkan daerah Ngaglik yang dapat mewakili karakteristik seluruh populasi.

Pengambilan data menggunakan wawancara. Metode analisis data yang digunakan adalah analisis deskriptif dengan pendekatan kualitatif dengan tahapan berikut, pertama mereduksi data yang merupakan suatu proses pemilihan, penyederhanaan, dan transformasi data kasar yang muncul dari catatan-catatan tertulis di lapangan. Pada tahap ini data yang didapatkan dari pihak BRI Syariah Kota Batu masih bersifat global tentang nasabah qardhul hasan. Kedua triangulasi data, pada tahapan ini adalah menganalisis informasi yang diperoleh dari catatan-catatan yang sudah direduksi untuk dilihat kebenarannya sambil mencari data pendukung sehingga hasilnya dapat dipercaya. Tahapan ini menggunakan wawancara dengan informan serta dokumentasi yang didapatkan dari unit head micro dan staf BRI Syariah Kota Batu. Selain itu penggalian informasi serta observasi dilakukan pada nasabah qardhul hasan pelaku usaha mikro kecil dan menengah tentang pelaksanaan pemberian dana, penggunaan dana serta perkembangan setelah menggunakan dana tersebut.

Tahapan selanjutnya yang ketiga adalah penyajian data, merupakan sekumpulan informasi dari tahap triangulasi dan memberi kemungkinan adanya penarikan kesimpulan dan pengambilan tindakan baik penyajian dalam bentuk tabel maupun naratif guna menggabungkan informasi yang tersusun kedalam bentuk yang terpadu. Dalam tahap ini sudah mendapat gambaran tentang model dan peran pemberian dana qardhul hasan pada nasabah mikro kecil dan menengah yang dilakukan oleh BRI Syariah Kota Batu. Terakhir, keempat adalah penarikan kesimpulan yang merupakan proses mencatat keteraturan, penjelasan tentang alur sebab akibat dari proses penyajian data. Kemudian kesimpulan-kesimpulan diverifikasi selama penelitian 
berlangsung dengan kata lain sebelum kesimpulan akhir dilakukan, dapat didahului dengan kesimpulan dalam proses sebelumnya. Kesimpulan-kesimpulan sementara tersebut dengan model interaktif memunculkan kesimpulan final yang kompeten dengan proposisi-proposisi penelitian. Tahap akhir ini memunculkan kesimpulan yang dapat menjawab tujuan penelitian yaitu model dan peran akad qardhul hasan pada usaha mikro kecil menengah yang dilakukan oleh BRI Syariah Kota Batu. Usaha mikro kecil menengah tersebut adalah penjual bakso, petani bunga potong, petani bunga hias, pedagang sembako dan toko kelontong.

\section{HASIL DAN PEMBAHASAN} (UMKM)

Model akad qardhul hasan di BRI Syariah Kota Batu Pada Pengusaha Kecil Dan Menengah

Wawancara dengan head micro BRI Syariah Kota Batu. Bagaimana cara bapak melakukan pemberian pinjaman dana gardhul hasan. Jawaban beliau sebagai berikut: "Pertama tim kami menawarkan pada pelaku usaha kecil mikro menengah (UMKM) tentang dana qardhul hasan, kemudian setelah tim kami mendapatkan nasabah dan mereka setuju atas dana gardhul hasan ini, lalu tim kami melakukan survei usaha mereka. Survei dilakukan dan ternyata memang benar atas usaha yang mereka miliki, maka pihak kami selaku pemberi pinjaman dana, membuat akad sesuai kesepakatan (Perjanjian Qardh). Dalam perjanjian ini BRI Syariah Kota Batu mengikuti Fatwa DSN 19/DSN-MUI/IV/2001: al-Qardh. Fatwa tersebut menyebutkan dana yang diberikan untuk usaha, seluruhnya dari bank.

Adapun tenaga kerjanya adalah dari nasabah sebagai pemilik usaha mikro kecil menengah. Biaya pengurusan pinjaman dana ini ditanggung oleh nasabah. Nasabah wajib mengembalikan seluruh pinjaman dana (Modal). Jika nasabah tidak dapat mengembalikan sebagian atau seluruh kewajibannya pada saat yang telah disepakati dan bank telah memastikan ketidak mampuannya, maka dapat memperpanjang jangka waktu pengembalian. Jika ada keuntungan tidak ada bagi hasil. Namun jika nasabah ingin memberikan kepada bank maka tidak dilarang" Wawancara sudah melalui pencocokan dengan nasabah penerima pinjaman dana gardhul hasan. Berdasarkan hasil wawancara, maka model akad gardhul hasan di BRI Syariah Kota Batu ini mendukung skema gardh yang digambarkan Suma (2017) sebagai berikut.

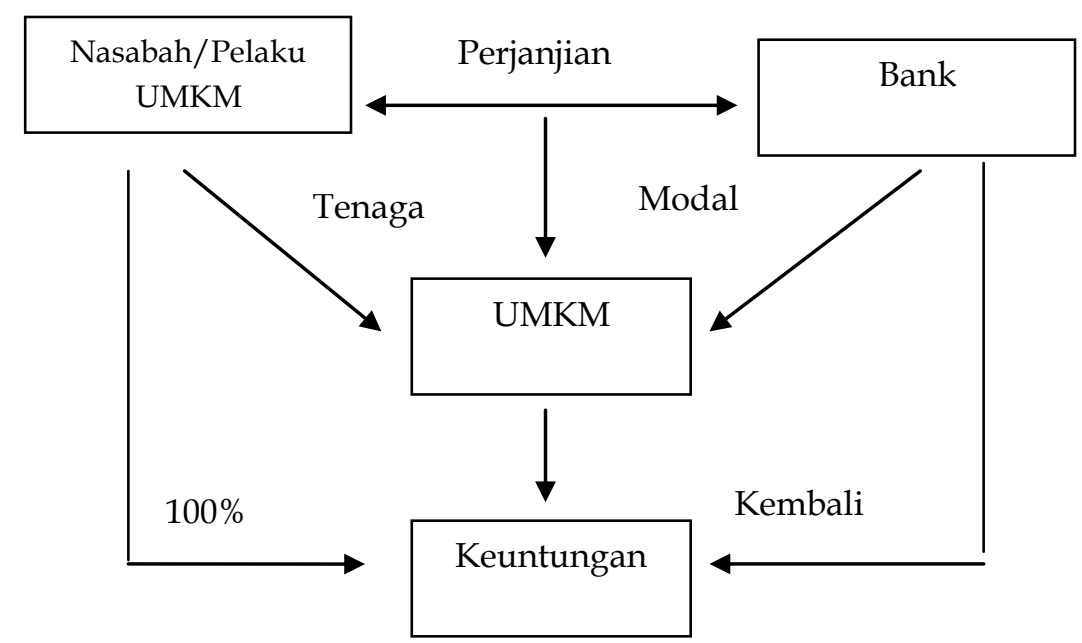

Gambar 1. Model Akad Qardhul Hasan di BRI Syariah Kota Batu 
Pelaksanaan pemberian qardhul hasan di BRI Kota Batu yaitu:

1) Menawarkan pada pemilik UMKM atas referensi nasabah atau teman dari pihak BRI Syariah Kota Batu

2) Setelah menawarkan lalu pihak BRI Syariah Kota Batu melakukan survei atas usaha yang dimiliki atau rencana usahanya

3) Membuat kesepakatan kemampuan mencicil

Setelah kedua belah pihak setuju maka diproses sesuai prosedur di BRI Syariah Kota Batu (sesuai Fatwa DSN 19/DSN-MUI/IV/2001: al-Qardh)

4) Kontrak perjanjian qardhul hasan dilaksanakan antara BRI Syariah Kota Batu dengan nasabah

5) Nasabah menyediakan tenaga untuk mengelola usaha dan BRI Syaraiah Kota Batu menyerahkan modal sebagai investasi. Modal yang diserahkan berasal dari dana kebajikan bank.

6) Dilakukan kunjungan satu kali dalam satu bulan untuk memberikan arahanarahan yang terkait dengan pemberdayaan masyarakat serta melihat perkembangan bisnis/usahanya.

7) Nasabah penerima dana qardhul hasan membuat laporan keuangan setiap bulan pada BRI Syariah

8) Pihak BRI Syariah terus memberikan motivasi untuk maintenance dan pengembangan atas usahanya

9) Memantau terus berjalannya usaha nasabah

10) Pada saat Jatuh tempo, maka nasabah mengembalikan $100 \%$ modal yang berasal dari BRI Syariah tanpa ada tambahan.

11) Jika mengembalikannya dengan cara mencicil dan terjadi penundaan maka akan di reschedule untuk pencicilan yang bisa mundur atau memperpanjang jangka waktu pengembalian atas kesepakatan bersama

Hasil temuan model qardhul hasan di BRI Syariah Kota Batu telah didukung oleh teori Ismail (2013) yang menjelaskan bahwa, kontrak perjanjian qardhul hasan dilaksanakan antara bank dan nasabah. Nasabah menyediakan tenaga kerja untuk mengelola usaha dan bank syariah menyerahkan modal sebagai investasi. Bila terdapat keuntungan, maka keuntungan 100\% dinikmati oleh nasabah, tidak dibagi hasil dengan bank syariah. Pada saat pembayaran atau jatuh tempo, maka nasabah mengembalikan 100\% modal yang berasal dari bank syariah tanpa ada tambahan.

\section{Peran Akad Qardhul Hasan Pada Pengusaha Kecil Dan Menengah (UMKM) Dalam Perkembangan Perekonomian Di BRI Syariah Cabang Kota Batu}

Rasulullah SAW mengajarkan kepada kita agar saling tolong menolong. Tolong menolong atau ta'awun merupakan kebutuhan hidup manusia yang tidak dapat dipungkiri. Kenyataan telah membuktikan, bahwa suatu pekerjaan atau apa saja yang membutuhkan pihak lain, pasti tidak akan dapat dilakukan secara sendirian meskipun dia seorang yang memiliki kemampuan dan pengetahuan tentang hal itu. Ini menunjukkan, bahwa tolong menolong dan saling membantu merupakan sebuah keharusan dalam hidup manusia. Allah subhannahu wa Ta'ala telah berfirman: 
"Dan tolong menolonglah kamu dalam mengerjakan kebajikan dan takwa, dan jangan tolong menolong dalam berbuat dosa dan pelanggaran. Dan bertakwalah kamu kepada Allah, sesungguhnya Allah amat berat siksaNya" (QS. Al-Maidah: 2).

Bahwasanya Abdullah bin Umar r.a mengabarkan, bahwa Rasulullah SAW bersabda: "Muslim yang satu adalah saudara muslim yang lain, oleh karena itu ia tidak boleh menganiaya dan mendiamkannya. Barang siapa memperhatikan kepentingan saudaranya, maka Allah akan memperhatikan kepentingannya. Barang siapa membantu kesulitan seorang muslim, maka Allah akan membantu kesulitannya dari beberapa kesulitannya nanti pada hari kiamat. Dan barang siapa menutupi (aib) seorang muslim, maka Allah akan menutupi (aib) nya pada hari kiamat" (HR Bukhari)

Ta'awun (saling tolong menolong) adalah merupakan salah satu cara menjaga ukhuwah Islamiah (persaudaraan dalam Islam). Tidak ada arti dan nilainya jika kita menganggap saudara tetapi kita tidak membantu saudara kita ketika memerlukan bantuan, dan menolongnya ketika dia ditimpa cobaan, serta belas kasihan ketika ia dalam keadaan lemah. Rasulullah SAW telah mengajarkan tujuan saling tolong menolong dalam bermasyarakat bagaikan bangunan.

Qardhul Hasan atau Al- Qard dikategorikan akad ta'awun (saling tolong menolong). Akad ini dijalankan untuk fungsi sosial bank. Bank memberikan pinjaman murni kepada orang kurang mampu untuk kepentingan produktif yaitu untuk pengembangan usahanya. Cara pengembaliannya bisa dengan cara diangsur atau dibayar tunai sekaligus (Hasan, 2014). Pengertian ini menunjukkan bahwa qardhul hasan dapat dimaknai sebagai fasilitas yang dapat mengembangkan usaha serta meningkatkan pembagunan ekonomi. Berikut ini adalah wawancara dengan nasabah penerima pinjaman dana qardhul hasan yaitu penjual bakso. Apa yang ibu rasakan setelah mendapatkan pinjaman dana qardhul hasan dari BRI Syariah Kota Batu. Apakah ada perkembangan usaha dari sebelum mendapatkan pinjaman dana dan sesudah mendapatkan pinjaman dana ini. Jawaban ibu tersebut adalah sebagai berikut:

"Sebelum saya mendapatkan dana ini saya masih bergabung dengan kakak saya berjualan daging sapi di Pujon, setelah saya mendapatkan tawaran ini saya membuat usaha sendiri dengan berjualan bakso. Alhamdulillah bakso ini banyak pembelinya karena saya kebetulan mendapat tempat di Ngaglik ini menempel temboknya kantor Samsat sehingga dibuat langganan oleh karyawan kantor Samsat. Selain itu sering dibeli oleh siswa sekolah SMA yang didekat dengan warung ini juga. Banyak pembeli yang menanyakan minuman kopi akhirnya saya juga menambah dagangan saya dengan kopi yang saya inovasi dengan atasnya saya beri toping. Alhamdulillah usaha bakso saya dapat berkembang, pendapatan saya juga meningkat sedikit demi sedikit dan saya bisa mencicil pinjaman saya dengan baik, serta saya sudah bisa mandiri tidak lagi bergabung dengan kakak saya berjualan daging sapi di Pujon"

Demikian pula wawancara dengan nasabah qardhul hasan yang lain yaitu pedagang sembako. Apa yang bapak rasakan setelah mendapatkan pinjaman dana qardhul hasan dari BRI Syariah Kota Batu. Apakah ada perkembangan usaha dari sebelum mendapatkan pinjaman dana dan sesudah mendapatkan pinjaman dana ini. Jawaban bapak tersebut adalah sebagai berikut:

"Saya mendapat dana ini untuk mengembangkan usaha saya yaitu berjualan sembako. Sebelum mendapatkan pinjaman ini, jika saya kula'an saya merasa kesulitan karena belum punya mobil untuk usaha. Setelah saya mendapatkan pinjaman dana ini saya bisa membeli mobil Tosa dari keuntungan usaha saya. Saya merasa lebih mandiri dengan memiliki mobil Tosa ini yang bisa saya gunakan untuk kula'an sembako. Bahkan terkadang saya sudah bisa melayani siap antar untuk pembeli yang rumahnya jauh. Alhamdulillah saya juga bisa mencicil pinjaman"

Informan-informan selain penjual bakso dan pedagang sembako yakni: toko kelontong, petani bunga petik dan petani bunga hias juga mengatakan bahwa mereka merasakan lebih 
mandiri dan mengalami perkembangan dalam usahanya selain dagangan bertambah juga adanya penambahan pendapatan. Mereka sama-sama bisa membeli mobil Tosa, karena mobil ini memang cocok untuk usaha.

Bertolak dari hasil wawancara serta didukung oleh ayat dan hadits serta teori dan hasilhasil penelitian terdahulu yang telah dikemukakan, maka dapat dijelaskan bahwa model pemberian pinjaman qardhul hasan yang dilakukan oleh BRI Syariah Kota Batu dapat meningkatkan perekonomian masyarakat dalam rangka pengentasan kemiskinan atau penanggulangan kemiskinan ini dapat terwujud dengan baik. Dengan demikian peran akad qardhul hasan pada Pengusaha Kecil Dan Menengah (UMKM) dalam perkembangan perekonomian Di BRI Syariah Cabang Kota Batu yaitu,

Dapat menciptakan rasa kemandirian pengusaha kecil dan menengah (UMKM) melalui peran fasilitatif dari pihak BRI Syariah Kota Batu yang benar-benar menjalan tugasnya sebagai fasilitatator kepada masyarakat pengusaha kecil dan menengah (UMKM) berdasarkan keadaan di lapangan. Mulai dari pemberian motivasi hingga sampai mau bertindak untuk maju dalam kehidupannya. Selain itu juga diperoleh dari peran edukasional dari pihak BRI Syariah Kota Batu memberikasn edukasi kepada para pengusaha kecil dan menengah (UMKM) sebagai nasabah qordhul hasan untuk bisa memulai bergerak dalam program perkembangan perekonomian.

Dapat menciptakan kreativitas untuk memulai dan mengembangkan usaha bagi pengusaha kecil dan menengah (UMKM) melalui peran perwakilan dari pihak BRI Syariah Kota Batu yang terarah dengan mengawasi program atau usaha yang dijalankan oleh pengusaha kecil dan menengah (UMKM). Selain itu juga diperoleh dari peran teknis yang dilakukan oleh BRI Syariah Kota Batu yaitu semangat kepada para pengusaha kecil dan menengah (UMKM) sebagai nasabah qordhul hasan untuk terus menjalankan dan mengembangkan usaha namun sehingga mereka dapat berkembang ide-ide usahanya dan memunculkan kreativitas. Dalam hal ini memang usaha dan aset mereka sudah berkembang sehingga telah terwujud turut mendukung perkembangan perekonomian di Indonesia pada umumnya dan di Kota Batu pada khususnya.

\section{KESIMPULAN DAN SARAN}

Kesimpulan yang dapat diambil dari penelitian ini bahwa, akad qardhul hasan yang dilakukan oleh BRI Syariah Kota Batu berdasarkan konsep syariah, yaitu pinjaman yang harus dikembalikan $100 \%$ pada saat jatuh tempo dengan tidak ada kelebihan. Jika akan dicicil sesuai kemampuan yang telah disepakai bersama antara kedua belah pihak yaitu pihak BRI Syariah dan pihak nasabah penerima dana qardhul hasan. Adapun peran akad qardhul hasan yaitu: (1) dapat menciptakan rasa kemandirian pengusaha kecil dan menengah (UMKM), (2) Dapat menciptakan kreativitas untuk memulai dan mengembangkan usaha bagi pengusaha kecil dan menengah (UMKM).

Saran yang diberikan adalah (1) agar akad qardhul hasan disosialisasikan lebih luas lagi supaya masyarakat lebih mengenal akad qardhul hasan tersebut. Jika sudah mengenal maka masyarakat akan dapat lebih mengembangkan dan memperluas usahanya, serta ikut mendukung perkembangan perekonomian di Indoneisa pada umumnya dan Kota Batu pada khususnya. (2) hendaknya masyarakat luas benar-benar mengetahui fungsi dari akad qardhul hasan agar tidak salah tujuan penggunaan dana 
qardhul hasan yang semestinya untuk pengembangan usaha dalam rangka perbaikan dan pengembangan ekonomi namun terbukti ada yang menggunakan dana qardhul hasan digunakan sebagai kebutuhan konsumtif sehingga hal ini akan tidak mendukung perkembangan perekonomian di Indoneisa pada umumnya dan Kota Batu pada khususnya

Keterbatasan yang dimiliki dalam penelitian ini adalah kurangnya informan dari pihak penerima dana (nasabah) qardhul hasan yaitu pelaku UMKM untuk menggali lebih rinci mengenal akad qardhul hasan dalam rangka perkembangan perekonomian dengan cakupan yang lebih luas. Hal ini dikarenakan nasabah qardhul hasan masih difokuskan pada daerah yang terdekat dengan kantor BRI Syariah Kota Batu.

\section{TINJAUAN PUSTAKA}

Antonio, S. (2001). Bank Syariah dari Teori ke Praktik. Jakarta: Gema Insani Press.

Arowana, A. (2017, Maret). Perttumbuhan Ekonomi Kota Batu di Atas Jatim dan Nasional.

Retrieved from Malang Voice: https://malangvoice.com/pertumbuhan-ekonomikota-batu-di-atas-jatim-dan-nasional/

Ascarya. (2012). Akad dan Produk Bank Syariah. Jakarta: Raja Grafindo Persada.

BAPPEDA. (2019). Rencana Program Investasi Jangka Menengah Daerah Kota Batu. Retrieved from http://sippa.ciptakarya.pu.go.id/sippa_online/ws_file/dokumen $\angle \mathrm{rpi}$ jm/DOCRPIJM_c5ebe983b9_BAB\%20IIRPIJM\%20Kota\%20Batu\%20Bab\%20II$\underline{\text { min.pdf }}$

Bilal, M. (2017). Optimalisasi Produk Qordhul Hasan Sebagai Optimalisasi Produk CSR pada Baitul Maal Tumang dalam Rangka Pengetasan Program Kemiskinan. Salatiga: Instirutr Agama Islam Negeri Salatiga.

Falikhatun, Y., \& U.A, H. (2016). Menelisik Makna Pembiayaan Qardhul Hasan dan Implementasinya Pada Perbankan Syariah di Indonesia. Jurnal Keuangan dan Perbankan , 2, 94-103.

Hafni, R. (2015). Analisis Usaha Mikro, Kecil, dan Menengah (UMKM) Terhadap Penyerapan Tenaga Kerja Di Indonesia dalam Jurnal Ekonomikawan. Retrieved September 5, 2019, from www.neliti.com: https://www.neliti.com/id/publications/78163/analisisusaha-mikro-kecil-dan-menengah-umkm-terhadap-penyerapan-tenaga-kerja-di

Hannanong, A. I. (2018). Al-qardh al-hasan: Soft and Benevolent Loan Pada Bank Islam. (I. Pare-Pare, Ed.) Retrieved from file:///C:/Users/DEKAN/Downloads/617Article\%20Text-892-1-10-20181205.pdf

Hasan, Nurul Ichsan. 2014. Perbankan Syariah (Sebuah Pengantar), Jakarta, Referensi

Ismail. (2013). Perbankan Syariah. Jakarta: Fajar Interpratama Mandiri

Karimah, S. (2015). Pembiayaan Qardhul hasanTerhadap Perkembangan Usaha Mikro (Studi Kasus BMT Al Husnayain Jakarta). Bandung: IPB.

MUI. (2001). Fatwa DSN NO 19/DSN-MUI/IV/2001 : Al-Qardh. Retrieved from http://sharialearn.wikidot.com/fdsn019 
Muiz, A. A. (2015, Agustus 4). Tiga Sektor Ini Jadi Andalan Kota Batu Dongkrak Perekonomian. Retrieved September 6, 2019, from Surya Malang: https://suryamalang.tribunnews.com/2015/08/04/tiga-sektor-ini-jadi-andalankota-batu-dongkrak-perekonomian

Muslehuddin, M. (2004). Sistem Perbankan dalam Islam. Jakarta: Rineka Cipta.

Putri, Y. R., \& Suryadi, N. (2018). Analisis Penerapan Biaya Qardhul Hasan Berdasarkan PSAK Syariah pada BMT Al Ittihad Rumbai Pekanbaru. Jurnal Islamic Banking and Finance, 1, 1-14.

Suma, A. (2017). Ekonomi Syariah. Bandung: Pustaka Syariah.

Sunariani, N. N. (2017). Pemberdayaan Usaha Mikro Kecil dan Menengah (UMKM) melalui program binaan di Provinsi Bali,. Jurnal Ilmiah Manajemen dan Bisnis , 2, 1-20.

Wulandari, P. (2019). Enhancing the role of Baitul Maal in giving Qardhul Hassan financing to the poor at the bottom of the economic pyramid: Case study of Baitul Maal wa Tamwil in Indonesia. Journal of Islamic Accounting and Business Research, 10, 382-391.

Zauro, N. A., Zauro, N. A., Saad, R. A., \& Sawandi, N. (2020). Enhancing socioeconomic justice and financial inclusion in Nigeria: The role of zakat, Sadaqah and Qardhul Hassan. Journal of Islamic Accounting and Business Research , 11 No 3, 555572 . 